\title{
Professoras iniciantes: formação, experiência e desenvolvimento profissional
}

Silmara de Oliveira Gomes Papi*

\section{Resumo}

Este artigo aborda a formação docente, tendo em vista o desenvolvimento profissional de professoras iniciantes. Busca explicitar a influência, no desenvolvimento profissional das professoras pesquisadas, de aspectos originados da experiência que se caracterizaram, em sentido amplo, como formativos. Desenvolveu-se um estudo de caso qualitativo de matriz crítico-dialética. Como instrumentos de coleta de dados foram utilizados o grupo focal, a entrevista semiestruturada e a observação participante. 0 estudo evidenciou que o desenvolvimento profissional das professoras pesquisadas é marcado por múltiplos intervenientes formativos gerados pela experiência vinculada à sua história pessoal, especialmente envolvendo a influência materna e as suas vivências como alunas dos anos iniciais de escolarização.

\section{Palavras-chave}

Professores iniciantes, formação docente, experiência, desenvolvimento profissional.
* Departamento de Educação, Universidade Estadual de Ponta Grossa (UEPG), Ponta Grossa, Paraná, Brasil. silmarapapi@ gmail.com 


\title{
Novice Teachers: Formation, Experience and Professional Development
}

\begin{abstract}
This article focuses on the professional development of novice teachers. It presents the results of a dialectical-critical qualitative study based on focal groups, semi-structured interviews and participant observation with a group of teachers that tried to understand the formative influence of experience in their professional development. The study showed that the professional development of the teachers was marked by multiple influences linked to their personal history. The influence of their mothers and their childhood school experiences seemed to be of particular significance.
\end{abstract}

Keywords Novice teachers, teacher formation, experience, professional development. 


\section{Introdução}

Compreendida em sentido amplo, a formação docente insere-se no âmbito da formação humana e das relações sociais, articulando-se ao processo de construção da vida em sociedade, sendo por isso marcada por rupturas e contradições. Ela se efetiva mediante uma atitude ativa em que, agindo sobre a realidade para produzir a vida material, mas também sendo influenciado por ela, o homem constrói sua identidade e o sentido de alteridade que lhe dá a referência do outro.

Em sentido restrito, a formação do professor objetiva prepará-lo para o exercício da docência, envolvendo um processo relacional e ativo, efetivado por uma instituição formadora e mediado pelo formador.

A formação é um dos elementos que contribui para o desenvolvimento profissional do professor ou para o seu processo de melhoria no ensino. Formalmente, o desenvolvimento profissional inicia-se com a formação inicial (Imbernón, 1998), embora, em sentido lato, outros elementos formativos se destaquem nesse processo.

0 presente artigo objetiva explicitar a influência, sobre o desenvolvimento profissional de professoras iniciantes, de aspectos da experiência (Thompson, 1981) que se caracterizam, em sentido amplo, como formativos. A experiência, para Thompson (1981, p. 15), é uma “[...] resposta mental e emocional, seja de um indivíduo ou de um grupo social, a muitos acontecimentos inter-relacionados ou a muitas repetições do mesmo tipo de acontecimento." São apresentados dados de um estudo que buscou compreender como se constitui o processo de desenvolvimento profissional de professores iniciantes.

A pesquisa desenvolveu-se em uma rede municipal de ensino e as professoras investigadas foram indicadas ${ }^{1}$ por gestoras de escolas municipais (pedagogas e diretoras) e da Secretaria Municipal de Educação - SME de um município paranaense. Após a realização de entrevistas com duas das gestoras da SME, ainda na fase exploratória da pesquisa, e de três grupos focais com pedagogas e diretoras de escolas em que atuavam professores iniciantes com o tempo de até cinco anos de exercício profissional (Imbernón, 1998) e sem atuação anterior no magistério, foram selecionadas duas professoras: Joana (Jo) e Luana ${ }^{2}(\mathrm{Lu})$.

Desenvolveu-se um estudo de caso de matriz crítico-dialética (Bernardo, 1991; Castoriadis, 1985; Thompson, 1981) que teve como eixo epistemológico a concepção da teoria como expressão

1. As professoras deveriam ser consideradas bem-sucedidas na profissão. Essa opção foi aleatória, sem intenção de discussão do mérito.

2. Os nomes das professoras e das escolas são fictícios, atendendo aos preceitos éticos da pesquisa. 
da prática (Martins, 2004, 2009). Para a coleta dos dados na fase formal da pesquisa, utilizou-se a observação participante, efetivada de uma a duas vezes por semana durante quatro meses nas escolas das professoras, e a entrevista semiestruturada, realizada individualmente em três etapas de aproximadamente uma hora e quinze minutos cada uma delas.

Os dados da observação, que se deu nas atividades e nos espaços em que permaneciam as professoras - sala de aula e de professores, reunião de pais, dia de organização do trabalho pedagógico/OTP -, foram registrados em diários de campo da pesquisadora (Diape). À luz de autores como André (2005a, b) e Lüdke e André (2005), a abordagem qualitativa foi privilegiada na coleta de dados e em sua análise.

0 texto está estruturado em três partes. Inicialmente, a partir da compreensão da história pessoal como articulada à formação do professor, destaca-se a influência materna vinculada à opção pela docência como profissão. Em seguida, discute-se o papel de professores dos anos iniciais de escolarização na prática pedagógica das professoras pesquisadas. Finaliza-se com algumas considerações sobre os dados apresentados.

\section{História pessoal: elementos formativos em sentido amplo}

Considerar a singularidade das pessoas, os aspectos idiossincráticos de sua história; a forma como agem em seu contexto e se relacionam com outras pessoas para produzir a própria vida e por que o fazem é relevante para compreender de que modo se constitui o professor, pois nesse percurso o "fazer" gera experiência e aprendizagens, cingindo a pessoa e o professor. Assim, analisar o desenvolvimento profissional docente não prescinde da compreensão de que "o professor é a pessoa e uma parte importante da pessoa é o professor”, conforme Nias (1991 apud Nóvoa, 2002, p. 57).

A experiência, decorrente das trocas sociais e originada no ambiente social e cultural, é elemento nodal para a constituição do professor. Isso implica considerar sua história de vida e a história da própria sociedade como vinculadas às possibilidades existentes, contribuindo para que se compreendam, “[...] assim, as escolhas, contingências e opções que se deparam ao indivíduo" (Goodson, 1995, p. 75).

A influência materna na escolha da profissão: busca de estabilidade e possibilidade de ascensão social

Joana é professora da Escola Municipal do Verde. Concluiu a formação em nível de magistério, tendo frequentado três instituições diferentes. No início de 2009, re- 
tornou ao segundo ano noturno do curso de Pedagogia, na instituição de educação superior pública da cidade em que reside, curso que havia iniciado em 1992 e abandonado em 1993.

Antes de ser professora da rede pública municipal, Joana trabalhou como auxiliar de nutricionista na cozinha do Pronto Socorro Municipal e, posteriormente, em um supermercado, na função de operadora de caixa. Destacando elementos de sua trajetória pessoal, aponta aspectos que se relacionam aos motivos que a levaram à escolha da profissão, ressaltando a importância da expectativa materna:

[...]: eu fiz magistério [...], me formei em 86, [...]. Mas eu não quis trabalhar com o magistério, [...] eu não gostava. Eu fiz porque minha mãe era zeladora de escola, ela queria, e eu fiz. [...]. Depois fui trabalhar em outra coisa, [...]. (Jo)

Minha mãe falava [...] que a melhor profissão pra mulher é ser professora. Porque acho que ela via lá na escola as professoras, [...]. [...]. Eu acho que antigamente eu até pensava um pouco [referindo-se a também ela pensar que a docência é para mulheres]. (Jo)

[...] Eu não sei, [...], acho que veio de antigamente, na cabeça das pessoas. [...]: a minha mãe era zeladora de escola, uma pessoa que estudou até a $4^{a}$ série. Eu acho que ela achava bonito aquela professora lá na frente, que tinha uma profissão estável, [...]. (Jo)

Ao afirmar que sua mãe era zeladora de escola e que havia estudado até a $4^{\text {a }}$ série do Ensino Fundamental, Joana parece evidenciar o quanto ela valorizava a profissão docente pelo que poderia representar para a filha, caso optasse por segui-la. Chama a atenção para o fato de que ela a incentivava a ser professora provavelmente porque “achava bonito aquela professora lá na frente" e, pela "estabilidade" que a profissão seria capaz de lhe proporcionar. Percebe-se que Joana compreende o motivo desse incentivo, relacionando-o ao acesso à profissão como possibilidade de ação diante da situação vivenciada, tendo em vista a busca de melhores condições de vida numa sociedade dividida em classes, em que relações de dominação e de exploração geram desigualdade econômica e social. 
Sobre o fato de a mãe de Joana valorizar a profissão docente, são relevantes as contribuições de Thompson (1981) para a compreensão desse processo. Para o autor, os valores não surgem espontaneamente, não são chamados nem pensados pelos sujeitos. Eles são vividos concretamente e nascem do vínculo com a vida material e as relações materiais a partir das quais passam a existir também as ideias.

Nesse sentido, se foi a partir das condições vivenciadas no trabalho e das limitações impostas pela situação vivida que a docência passou a ser valorizada pela mãe de Joana, essa valorização é também a expressão do que era vivido socialmente naquele momento, em sentido mais amplo.

Formada em magistério na década de 1980, percebe-se que, nesse período, o acesso à educação era entendido como garantia de benefícios ou possibilidade de avanço socioeconômico, encarado como uma oportunidade que somaria positivamente, uma vez que a qualificação por meio de um nível preciso de formação era vista e valorizada, naquele momento histórico, como "requisito de promoção social [...]", tal como ocorrera nas décadas de 1960 e 1970 mediante o pano de fundo desenvolvimentista, segundo as análises de Canário3 (2000, p. 37, grifo do autor) e de Aranha (2006). Isso demonstra que a escolha profissional de Joana está vinculada mais especificamente ao atendimento da necessidade de produção da vida material ${ }^{4}$, para o que a profissão docente representaria um movimento ascendente, tendo em vista as condições de sua família.

Luana, a segunda professora que compõe este estudo, pertence à Escola do Campo. Tem formação em magistério, concluído em 1998 em um Instituto de Educação. É formada em Pedagogia e em Psicopedagogia. Anteriormente ao seu ingresso na profissão, atuou como agente comunitária e, posteriormente, como auxiliar de odontologia.

Quando destaca o motivo que a levou a optar pela docência, Luana também ressalta a influência familiar, principalmente a materna, associando-a ao baixo nível de escolarização de sua mãe e às possibilidades amplas de campo de trabalho vislumbradas por ela, conforme evidenciam suas falas:

3. Canário (2000) desenvolve uma crítica ao debate sobre a aprendizagem ao longo da vida e faz referência à formação a partir da realidade europeia, embora suas considerações aproximem-se da história da formação de professores no Brasil, dada a influência sofrida por esse país.

4. Sobre o cenário estrutural do Brasil, ver BENJAMIN, Cesar et al. A opção brasileira. Rio de Janeiro: Contraponto, 1998.
Eu tenho mais quatro primas que são professoras, [...] A mãe também influenciava, também queria. [...], mas a mãe também tinha um gosto... E aí quando eu fui fazer o curso, já via minhas primas trabalhando, fazendo as coisas do magistério, [...] e achava bonito. 
Então, [tinha] incentivo mesmo da própria familia, pra fazer. E quando cheguei ao curso, eu gostei. [...]. (Lu)

Talvez porque ela [a mãe] quisesse, ela não estudou, não teve oportunidade. Mas também porque as minhas primas já trabalhavam, ela também queria, mais na certeza de ter um campo de serviço. [...] a minha irmã, ela fez Serviço Social, [...], mas não conseguiu trabalhar na área. E ela está fazendo Pedagogia [...], porque tem mais campo de trabalho, então, [...] a mãe ficou feliz. (Lu)

Embora demonstre posição contraditória, ora indicando ter sido a possibilidade da existência de campo de trabalho um dos motivos do incentivo materno, ora negando tal posição, Luana indica, em suas declarações, que o acesso à profissão docente foi percebido por sua mãe como possibilidade de ascensão social para ela, a filha. Como a mãe não tinha tido oportunidade de estudar, incentivou Luana a fazê-lo.

0 gosto e o interesse em exercer a profissão são associados às oportunidades de trabalho existentes, na medida em que Luana demonstra concordar com uma prima que relaciona o campo de trabalho ao fato de que sempre irão nascer crianças, e, consequentemente, sempre haverá necessidade de professores, como se pode observar:

[...]. Teve uma prima minha que falou: "Ah, quer uma profissão, faça Pedagogia, porque criança sempre está nascendo e sempre vai nascer, você sempre vai ter serviço". Ai eu falei: "Ah, mas é verdade", e fui. [...]. [...] no curso foi a mesma coisa, porque quando eu estava fazendo magistério, eu gostei, do começo até o fim. [...]. (Lu)

A identificação de Luana com o curso de magistério, quando o realizou, foi imediata, o mesmo ocorrendo com a graduação em Pedagogia, procurada assim que terminou o magistério, o que evidencia seu interesse e seu gosto pela área da educação, gosto que não exclui, inclusive, a percepção do vasto campo de trabalho que a área propicia.

$\mathrm{Na}$ escolha profissional, entretanto, embora Joana e Luana tenham revelado imperativos familiares no processo decisório que as levou à opção pela docência como profissão, observam-se diferenças quando relatam o gosto inicial por exercê-la. 
Como Luana, desde o início, tinha a pretensão de ser professora, a exemplo de outros familiares, isso evidencia uma trajetória com menos eventos impactantes no que concerne a essa escolha. Joana, por sua vez, afirma não ter apreciado, inicialmente, a profissão e a formação no curso de magistério, tendo somente mais tarde desenvolvido gosto por ela.

Ao evidenciar que, inicialmente, não simpatizava com a profissão, Joana expressa um conflito entre o que sua mãe gostaria que fizesse - e que foi possível fazer, inclusive porque a docência era vista também como uma profissão a ser exercida por mulheres 5 - e fato de que naquele momento talvez não fosse a profissão que queria seguir:

[...] primeira opção, por causa da mãe, que falou que era interessante fazer, porque é bom pra trabalhar... Segundo, porque não tinha mais opção de escolha. [...]. (Jo)

Minha mãe achava que era uma coisa boa, porque é coisa de mulher, não é? Aquele pensamento de mãe... Mas no fundo, agora eu vejo que ela estava correta, $[\ldots]$.

Eu percebi que eu nasci pra isso, pra ser professora. Depois de muito vai e volta, eu gosto do que eu faço. Eu gosto das crianças, é claro que de vez em quando "a gente briga", entre aspas, mas eu gosto de educá-las, [...].

[...] acho que porque ela trabalhava em escola, você sabe que mãe que trabalha em escola [...] sempre puxa, [...], ela se aposentou como zeladora de escola. [...]. (Jo)

A questão do papel social a ser desempenhado pela mulher aparece nas considerações de Joana quando expressa o posicionamento assumido por sua mãe, embora destaque que, em alguns momentos, tenha compartilhado desse posicionamento. Joana demonstra atribuir seu acesso à formação docente tanto à influência materna

5. Embora estejam presentes nos dados levantados as questões de gênero, dadas as peculiaridades deste texto, elas não são abordadas em profundidade. quanto à percepção de que a docência é uma profissão a ser exercida por mulheres.

Esse pensamento tem sido, muitas vezes, a ex- 
pressão da relação hierárquica e patriarcal que por muito tempo foi predominante nas relações familiares, bem como das coerções sociais impostas à mulher, devido à interpretação equivocada de sua condição de inferioridade.

Soma-se a essas questões a percepção social e historicamente construída de que a mulher tem aptidões que se desenvolvem desde o seu nascimento, sendo o ensino para crianças a oportunidade de colocá-las em prática. Conforme Garcia e Anadon (2006), essa percepção que tem a ver com a função materna - que envolve princípios de atenção, afeto e cuidados - ainda é associada ao exercício do magistério nos anos iniciais de escolarização.

As conclusões de Garcia e Anadon (2006) confirmam os achados de Fanfani (2006), obtidos em um estudo realizado no ano de 2003 - em que comparou o ofício docente nas realidades brasileira e argentina, tendo em vista as características sociodemográficas dos docentes e sua posição na estrutura social - no qual evidencia a presença predominantemente feminina nesse nível de ensino. Fanfani (2006) demonstra que, no Brasil, nos anos iniciais do Ensino Fundamental, 89,5\% da população docente urbana é mulher, enquanto no Ensino Médio tal porcentagem diminui para $66,6 \%$.

Cabe ressaltar, ainda, que conforme dados da UNESCO (2004) sobre o perfil dos professores brasileiros ${ }^{6}$ atuantes no Ensino Fundamental e Médio em escolas urbanas, $81,3 \%$ são mulheres e $18,6 \%$ são homens, sendo que a atuação feminina se dá em sua maioria no Ensino Fundamental, como evidenciado por Fanfani (2006).

Outro aspecto que chama a atenção no depoimento de Joana é o conflito expresso, ao declarar, inicialmente, não ter a intenção de seguir a profissão docente e, após ter concluído o magistério, recusar-se a trabalhar na área quando foi convidada a fazê-lo. Ela declara:

[...] quando eu terminei o magistério fui convidada pra trabalhar com crianças de cinco a seis anos, [...], eu acho que não era concursada, ainda, não me lembro como é que era esse tempo, [...]. Só que eu não quis, [...], achava que não era aquilo.

Mas hoje em dia eu não me vejo atrás de um balcão, eu não me vejo outra coisa, a gente muda, não é? (Jo)

6. De acordo com a UNESCO, a amostra foi construída de maneira que seja possível fazer inferências para a totalidade dos professores brasileiros do Ensino Fundamental e Médio, atuantes em escolas urbanas. 
Percebe-se nos depoimentos de Joana que “depois de muito vai e volta" (Jo) na trajetória profissional, ela parece ter se sentido motivada a exercer o magistério. Isso ocorreu à medida que passou a gostar do que estava fazendo, principalmente após a experiência gerada com os alunos, tendo em vista a perspectiva de contribuir com sua formação.

Joana demonstra ter passado por um processo de adesão à profissão (Nóvoa, 1995), isto é, ter valorizado, a partir da prática, a possibilidade de contribuir com a formação e a aprendizagem dos alunos, tendo, por isso, reforçado sua identificação com ela. Assim, a construção de novas percepções sobre a docência, mediada pela prática pedagógica na qual se pode incluir a relação pedagógica com os alunos, parece ser um aspecto que mantém Joana na profissão. A posição de Thompson (1981, p. 17) ilustra essa interpretação sobre a experiência de Joana:

A experiência entra sem bater à porta e anuncia mortes, crises de subsistência, guerra de trincheira, desemprego, inflação, genocídio. Pessoas estão famintas: seus sobreviventes têm novos modos de pensar em relação ao mercado. Pessoas são presas: na prisão, pensam de modo diverso sobre as leis. Frente a essas experiências gerais, velhos sistemas conceptuais podem desmoronar e novas problemáticas podem insistir em impor sua presença.

Se o gosto pela profissão surgiu especialmente depois de ter iniciado seu exercício, portanto, a partir da prática vivenciada por Joana, o processo decisório que a levou a optar e a decidir exercer a profissão se deu especialmente mediante três acontecimentos específicos.

Esses acontecimentos, que se referem à ocorrência de um problema de saúde; a uma tarde vivida como docente, de maneira informal; e ao incentivo da família e dos amigos para fazer o concurso municipal, no ano de 2000, podem ser considerados como incidentes críticos (Goodson, 1995), porque, tendo ocorrido ao longo de sua vida, foram capazes de afetar sua percepção e prática profissionais.

Sobre o problema de saúde pelo qual passou, Joana declara que, como tinha estado gravemente adoecida, passou a perceber a vida de forma diferente: não poderia mais desconsiderar as oportunidades dadas, dentre as quais o exercício da docência.

Além disso, Joana relata que já havia deixado o emprego no comércio desde o nascimento de sua filha, e, um ano antes de fazer o concurso público para atuar como professora na rede municipal - incentivada pelo marido e uma amiga -, foi convidada para trabalhar voluntariamente com um grupo de alunos dos anos iniciais do Ensino 
Fundamental. Sabendo da sua formação em magistério, a então diretora da mesma escola em que hoje trabalha solicitou-lhe ajuda, pois estava com falta de professores.

A vivência de uma tarde como colaboradora da escola é percebida por Joana como um marco relevante, pois revela que, daí em diante, passou a pensar na possibilidade de trabalhar como professora, principalmente por ter acreditado que conseguiria desenvolver o trabalho pedagógico ${ }^{7}$ com os alunos e por relacionar-se bem com eles.

A experiência constituída naquele momento, ainda que breve, demonstra ter sido intensa o suficiente para influenciar as decisões sobre sua vida, fazendo-a ver de forma diferente as possibilidades profissionais presentes e futuras. Portanto, a partir dessa atuação prática, Joana redefine sua opção de escolha profissional: “Aí eu [...] gostei, eu percebi que eu dava conta do recado, porque até então eu tinha medo de não dar conta de explicar pras crianças, de cuidar de uma turma, ai eu percebi que eu tinha". (Jo)

A preocupação de Joana com a relação a ser estabelecida com os alunos como um dos fatores que lhe causava receio para decidir exercer a profissão é um dos grandes desafios enfrentados por professores em início de carreira, especialmente no que diz respeito à manutenção da disciplina dos discentes (Lima, 2006; Vieira, 2002).

Além disso, a centralidade dessa preocupação pode ser ainda a expressão da formação inicial vivenciada e da forma como pode ter sido construída, especificamente a partir dela, a compreensão da relação professor-aluno na escola, muitas vezes entendida com bases autoritárias.

As considerações de Joana evidenciam, portanto, que a experiência gestada na vida em família e as contradições da prática social vivenciadas por ela agiram como uma força propulsora do mundo real (Thompson, 1981), provocando ações em busca de superação e de mudança em relação ao que estava posto.

\section{0 papel desempenhado por professores dos anos iniciais de escolarização na Educação Básica: a retomada consciente de um modelo}

Outro aspecto apontado por Joana e Luana, e que evidencia uma ação formativa vinculada à construção de práticas e percepções - embora não intencional - para as duas professoras, é o papel desempenhado pela experiência originada como alunas nos anos iniciais na Educação Básica. Elas assim se manifestam:
7. Considera-se trabalho pedagógico tanto a atuação direta do professor em sala de aula, no processo ensino-aprendizagem, quanto atividades que envolvem as gestoras da escola (diretora e pedagoga), considerando esse mesmo processo e a implementação do Projeto Político Pedagógico. Assim, a prática do professor em sala de aula, as atividades de planejamento, a utilização de espaços coletivos para a tomada de decisões sobre a escola, as atividades da gestão escolar, são entendidas como concernentes ao trabalho pedagógico. 
Tenho [lembrança], lá do comecinho. De todos eu lembro, do começo eu lembro. [...]. Do magistério não lembro, não consigo lembrar, e de Pedagogia, então, do primeiro ano que eu fiz, não vem ninguém na cabeça, sabe? (Jo)

Tem, eu acho que, principalmente as professoras de $1^{a} \grave{a} 4^{a}$, porque quando você chega na sala de aula, você sempre lembra aquela referência, às vezes um trabalho que a professora fez, que fica marcado. Professora de $1^{a} a 4^{a}$. De $5^{a}$ a ${ }^{a}$, já não tanto, [...]. (Lu)

Para Goodson (1995), há, entre os docentes, a lembrança de um professor anterior que os influenciou e ao seu exercício profissional, que lhes serve como um referencial. Assim, pela experiência constituída pelo aluno, quando vivencia a relação pedagógica, e pelos significados construídos a partir dessa experiência, os professores que servem de modelo chegam a influenciar “[...] provavelmente a visão subsequente da pedagogia desejável, e bem assim, possivelmente, a escolha do próprio curso (especialização, em termos de matéria de ensino)" (Goodson, 1995, p. 72).

Tal como destacado por Goodson (1995), as duas professoras, iniciantes na profissão, explicitam também a relação da sua prática pedagógica com práticas vivenciadas como alunas nos anos iniciais de escolarização, o que pode ser percebido quando estabelecem uma analogia entre as professoras que são e a vivência experienciada, conforme se verifica em seus depoimentos:

Lembro que as professoras, elas trabalhavam no sistema tradicional, é lógico, porque faz tempo, [...], mas, elas eram boas professoras... (Jo)

Porque eu me lembro que elas eram, [...] dedicadas, elas ensinavam mesmo, sabe? Elas trabalhavam mesmo com você. Eu lembro alguma coisa, que elas escreviam no quadro, ainda, o jeito delas!

Eu acho que porque elas eram dedicadas, elas trabalhavam mesmo! Talvez por isso, [...] fazendo uma relação, é que eu trabalho desse jeito, pra ensinar de verdade, não fazer de conta, [...] porque eu me lembro delas. (Jo)

Mas tem relação, eu sempre lembro assim das professoras, do jeito que elas falavam, de coisas que eu gostava que elas fizessem, escrevessem, [...], 
quando elas escreviam no caderno: "Muito bem, gostei", sabe aquele elogio quando a professora escreve, não o carimbo, sabe? Eu me lembro de uma professora da terceira série, que ela escrevia assim: "Gostei muito de você", [...], ela não escrevia só "Muito bem", solto, ela escrevia mais, "Gostei do que vocêfez, continue se esforçando". Ai eu também procurava escrever pras crianças um recadinho, pra ser mais pessoal, então, acho que influenciava bastante. (Lu)

Nos excertos das entrevistas, ainda que exista congruência quanto à contribuição do que vivenciaram como alunas nos anos iniciais da Educação Básica, há também uma diferença sensível em suas percepções.

Joana demonstra que a experiência constituída na escola, como aluna, é resultado da relação pedagógica estabelecida por seus professores, principalmente no espaço da sala de aula, e dos possíveis conflitos advindos dessa relação, denotando um posicionamento crítico, porém aparentemente contraditório, em relação a esse aspecto.

A professora afirma que aprendeu com suas professoras dos anos iniciais a ser responsável e a ter compromisso com o ensino. Para ela, ser professor é trabalhar com dedicação, e ser dedicada é ensinar “mesmo” (Jo), comprometendo-se com a aprendizagem discente. Suas afirmações, entretanto, revelam que qualifica a prática pedagógica daquelas professoras como tradicional, principalmente referindo-se à metodologia de ensino utilizada por elas. Joana afirma:

[...]. Também acho que não tinham essa visão antigamente, nos anos iniciais, porque eram mais tradicionais, eu lembro assim que era bem tradicional, você quase não brincava muito, era mais em sala de aula mesmo. É claro que isso foi bom, porque a gente aprendeu!

[...] em sala de aula, hoje em dia, a gente deixa os alunos falarem, eles falam, eles expõem ideias, e é isso que eu falo pra eles, nesse sentido é que eu quero desenvolvê-los. (Jo)

Ao referir-se especificamente à pedagogia tradicional, Joana demonstra ter experimentado as relações advindas dessa prática e tê-las articulado, em alguma medida, a pressupostos teóricos a que teve acesso na formação inicial ou continuada. Embora destaque que essa prática era consoante com aquele momento histórico, não 
demonstra ter clareza de seus pressupostos políticos e teóricos, mesmo percebendo que seus atuais alunos “[...] têm uma vida difícil” (Jo) e que, para viver melhor em sociedade, precisam aprender a participar mais ativamente dela.

Joana nasceu em 1967 e frequentou o então denominado $1^{0}$ Grau $^{8}$ na década de 1970 e início de 1980, quando se exigia do professor competência técnica para responder às expectativas desenvolvimentistas instituídas no período. Todavia, ao lado da vertente tecnicista, que atendia às demandas de produção vigentes, permaneciam os pressupostos de submissão e disciplinamento da pedagogia tradicional. Isso ocorria até porque as diferentes práticas pedagógicas que gradativamente se constituíram ao longo de cada período histórico não foram e não são mutuamente excludentes, pois foram - e ainda podem ser - muitas vezes encontradas nas diferentes situações pedagógicas.

Em suas falas, observa-se que Joana faz menção às práticas pedagógicas que vivenciou, criticando-as em alguma medida, especialmente quando refere que eram pouco flexíveis. Além disso, destaca ainda o uso do quadro de giz, o que ocorria possivelmente para favorecer uma estratégia frontal de ensino, centrada no professor e voltada à repetição de atividades e à memorização de conceitos.

Assim, se, por um lado, Joana questiona essa prática, em especial em termos das metodologias de ensino utilizadas e das relações sociais praticadas, por outro lado, evidencia a compreensão de que as professoras “ensinavam mesmo" (Jo), o que associa às maneiras de ser das docentes e ao seu alto nível de dedicação.

Trazidas para o presente, tais percepções parecem gerar uma tensão quando se confrontam com questões atuais que a desafiam: ao mesmo tempo em que classifica aquela organização pedagógica como tradicional, Joana reconhece sua capacidade de gerar aprendizagem. A noção de dedicação docente, por sua vez, revela-se um elemento que ela valoriza, ainda que não consiga percebê-lo dissociado da pedagogia tradicional. Ou seja, coexistem as compreensões de que as professoras seguiam a pedagogia tradicional e não davam abertura para a participação dos alunos, submetendo-os à ordem estabelecida, e de que, ainda assim, eram boas professoras e com elas os alunos aprendiam.

Thompson (1981, p. 16) afirma que nenhuma forma de ser social pode ser pensada sem que sejam considerados “[...] seus conceitos e expectativas organizadores [...]",

8. Assim chamado, quando em vigor a Lei 5692/1971. Hoje é denominado de Ensino Fundamental. surgidos com a experiência e, portanto, desde a atividade humana racional. Assim, no processo 
de desenvolvimento profissional de Joana, determinadas percepções contraditórias coexistem; geradas no campo da prática, elas expressam as relações que se inserem nessa prática.

Para a professora, é relevante que os alunos participem do processo ensino-aprendizagem de forma ativa, pois isso valoriza sua participação e a expressão de suas ideias para que possam ser respeitados e ativos nas relações estabelecidas em sociedade. Fica evidenciado, ainda, o questionamento aos princípios rígidos que vivenciou como aluna nos primeiros anos de escolarização, princípios que, a seu ver, não foram facilitadores da sua formação a partir de pressupostos mais participativos.

Percebe-se que existem intenções de mudança em seu questionamento, geradas na experiência resultante da prática social, no que diz respeito ao tipo de relações sociais que, entende, precisam ser estabelecidas: relações não autoritárias e mais horizontalizadas.

Entretanto, mesmo expressando essa compreensão - ainda que de forma pouco sistematizada -, Joana afirma que, sendo rígido, o professor garante que o aluno aprenda, o que conduz à percepção de um conflito que pode estar vinculado às condições e às relações vivenciadas na escola, as quais, segundo Martins (2004, 2009), são a expressão da relação social básica existente na sociedade capitalista, isto é, a relação entre trabalhadores e capitalistas, que tem como fundamento a exploração. Como afirma a autora (2004, p. 53), “é essa relação social básica que determina como vão ocorrer as diferentes práticas, como se caracteriza a relação pedagógica em diferentes momentos históricos", o que se explica pelo caráter totalizante do capitalismo, que envolve as diferentes instituições e lhes impõe uma lógica de submissão, competitividade e individualismo, necessária para a manutenção do modo de produção vigente.

Em meio ao conflito explicitado, verificou-se que Joana desenvolve uma prática pedagógica que deixa possibilidades limitadas de participação e de desenvolvimento da autonomia dos alunos, como é possível observar em alguns dados do diário de campo:

Alguns alunos querem mostrar a atividade para a professora e ela pede-lhes que se precisarem levantem a mão porque ela vai até suas carteiras, senão "Vira bagunça". E diz: "Vamos ver o exercício." Lê a orientação para os alunos, que era para completar as lacunas das palavras correspondentes aos desenhos, com a letra ' $i$ '. Faz cada desenho da folha no quadro e completa 
com eles cada palavra: lápis, igreja, iate, avião, imagem, pipa, ilha, índio. [...]. Faz de uma em uma palavra no quadro, e os alunos vão copiando (Diape 3, Jo).

Os elementos observados no excerto anterior remetem a uma prática em que, muitas vezes, as atividades são conduzidas de forma mecânica, tendo também baixo nível de relevância para os alunos. Além disso, é possível observar que desconsideram sua história e não valorizam os saberes oriundos da prática, mantendo-se centradas no professor e favorecendo relações hierarquizadas e pautadas na transmissão-assimilação passiva do conteúdo. Tais características são consoantes com as considerações de Martins (1989), quando descreve os pressupostos da escola tradicional, permitindo que sejam compreendidas em referência a esse modelo.

Martins (1989, p. 41) afirma que, nessa prática, o professor é o centro do processo e que "a ele cabe selecionar o saber sistematizado, ordená-lo de forma lógica e transmiti-lo ao aluno, que passivamente o recebe através do método expositivo e/ou demonstrativo". Tal encaminhamento pedagógico evidencia, por isso, a contradição vivenciada pela professora.

Em relação ao depoimento de Luana e às percepções que construiu a partir da experiência como aluna da Educação Básica, destaca, inicialmente, a contribuição de uma das suas professoras, valorizando os elementos afetivos que ela estabelecia com os alunos na prática pedagógica. Ao afirmar que repetia a prática desenvolvida por uma de suas professoras, isto é, que procurava escrever um "recadinho" para as crianças, para ser mais pessoal, Luana demonstra que a atitude afetuosa, que resultava como uma motivação para os alunos, foi um elemento importante para sua própria aprendizagem, passando a ser também um aspecto considerado relevante para a aprendizagem dos seus alunos.

Outro aspecto que Luana ressalta em seu depoimento está relacionado às metodologias de ensino de algumas de suas professoras, práticas que parecem ter exercido o papel de modelos que procurou retomar nesse período inicial de aprendizagem da profissão. Sobre essas práticas, ela expressa:

Uma professora também, do terceiro ano, [...], eu lembro que ela me pediu pra fazer uma produção de texto, [...]. Então eu escrevi um texto, [...] uma história de uma borboleta, [...] e no outro dia ela [...] elogiou bastante, [...]. 
[...]. Mas eu lembro que essas professoras sempre incentivaram os alunos principalmente a ler e escrever, tanto que eu gosto de escrever e de ler. E na sala eu também sempre procurava incentivar as crianças a escrever [...]. (Lu)

As [professoras] dos anos iniciais são as que marcam, que são as que a gente lembra. [...]. Tanto que quando eu peguei a turma de quarta série, [...] tinha lá sistema respiratório, já lembrava o que a professora fez, com as bexigas, aî já fazia também. [...]. Você tem a vivência, principalmente assim, conteúdo de ciências, como é que a professora fez, por exemplo, o mapa politico, [...]. Aíjá procurava fazer. [...]. (Lu)

Para Luana algumas professoras tiveram papel de relevância em seu exercício profissional. Sendo uma professora em início de carreira, ela destaca que o que vivenciou como aluna influiu concretamente em sua prática pedagógica, possivelmente como uma possibilidade de responder aos desafios encontrados nessa mesma prática, o que, em certa medida, coloca em xeque a formação profissional recebida na graduação, pois deixou de sistematizar esses elementos a fim de que fossem reorganizados em uma nova perspectiva.

Para Feiman (1983 apud Marcelo, 1999), a formação anterior à inicial é considerada como um nível diferente de formação ou como uma das fases do aprender a ensinar, à qual denomina fase de pré-treino e inclui o que os professores viveram antes da formação inicial, geralmente na condição de alunos em seus processos de escolarização.

Entretanto, embora Marcelo (1999) destaque que essa formação pode influenciar inconscientemente o professor, é possível perceber que Luana, em especial, afirma recorrer ao que vivenciou como aluna da Educação Básica de maneira direta e consciente, reproduzindo tal vivência e apontando para uma possibilidade diferenciada de compreender a influência desse espaço de formação geral, em relação à prática do docente iniciante, isto é, como uma formação que chega mesmo a incidir objetivamente sobre ela.

\section{Considerações Finais}

Os dados encontrados evidenciam que o desenvolvimento profissional das professoras pesquisadas é marcado por múltiplos intervenientes formativos, - muitas 
vezes determinantes - que se relacionam à experiência desencadeada por sua história pessoal.

Foi significativa a percepção da possibilidade de ascensão social das professoras representada pelo acesso e pelo exercício da profissão. Foi decisivo, ainda, o incentivo materno para a opção pela docência e, especificamente em relação à Joana, a percepção da docência como uma profissão feminina.

A influência das práticas de professoras dos anos iniciais da Educação Básica, retomadas mais conscientemente por Luana, foi também um aspecto que se destacou em seu desenvolvimento profissional, provavelmente na tentativa de minimizar as dificuldades percebidas por elas no exercício inicial da docência. Tal constatação corrobora os dados apresentados por Goodson (1995), mas também avança, quando aponta para outra forma de se perspectivar o que pode representar a experiência que as professoras constituíram como alunas, indicando o que pode significar em relação à fase de pré-treino.

Assim, a partir da ação prática e da constituição do próprio eu nesse movimento, criam-se sentidos e concepções, inclusive sobre a prática docente, e esses sentidos, vindos da experiência, articulam-se novamente à prática, esboçando-lhe possíveis contornos. Vê-se, portanto, que o ser humano confunde-se com o profissional, marcando-o com suas características e evidenciando a impossibilidade de ser compreendido isoladamente. 


\section{Referências bibliográficas}

ANDRÉ, Marli Eliza Dalmazo Afonso de. Estudo de caso em pesquisa e avaliação educacional. Brasília: Liber Livro, 2005a.

ANDRÉ, Marli Eliza Dalmazo Afonso de. Etnografia da prática escolar. Campinas: Papirus, 2005b.

ARANHA, Maria Lúcia de Arruda. História da Educação e da Pedagogia. São Paulo: Moderna, 2006.

BERNARDO, João. Economia dos conflitos sociais. São Paulo: Cortez, 1991.

CANÁRIO, Rui. A “aprendizagem ao longo da vida”: análise crítica de um conceito e de uma política. Psicologia da Educação, São Paulo, n. 10, p. 29-52, 2000.

CASTORIADIS, Cornelius. A experiência do movimento operário. São Paulo: Brasiliense, 1985.

FANFANI, Emilio Tenti. El oficio del docente en Argentina y Brasil: características sociodemográficas y posición en la estructura social. In: FELDFEBER, Myriam; OLIVEIRA, Dalila Andrade Oliveira (Comp.). Políticas educativas y trabajo docente. Buenos Aires: Centro de Publicaciones Educativas y Material Didáctico, 2006.

GARCIA, Maria Manuela Alves; ANADON, Simone Barreto. Reforma educacional, intensificación del trabajo docente, cuidado y gênero. In: FELDFEBER, Myriam; OLIVEIRA, Dalila Andrade Oliveira (Comp.). Políticas educativas y trabajo docente. Buenos Aires: Centro de Publicaciones Educativas y Material Didáctico, 2006.

GOODSON, Ivor F. Dar voz ao professor: as histórias de vida dos professores e o seu desenvolvimento profissional. In: NÓVOA, A. (Org.). Vidas de professores. 2. ed. Porto: Porto Editora, 1995.

IMBERNÓN, Francisco. La formación y el desarollo profesional del profesorado: hacia una nueva cultura profesional. 3. ed. Barcelona: Graó, 1998.

LIMA, Emília Freias de. (Org.). Sobrevivências no início da docência. Brasília: Liber Livro, 2006.

LÜDKE, Menga; ANDRÉ, Marli Eliza Dalmazo Afonso de. Pesquisa em Educação: abordagens qualitativas. São Paulo: EPU, 2005.

MARCELO, Carlos. Formação de Professores - para uma mudança educativa. Porto: Porto Editora, 1999.

MARTINS, Pura Lúcia Oliver. A didática e as contradições da prática. Curitiba: Ibepex; Campinas: Papirus, 2009.

MARTINS, Pura Lúcia Oliver. Didática teórica/didática prática: para além do confronto. São Paulo: Loyola, 1989. 
MARTINS, Pura Lúcia Oliver. Princípios didáticos na ação docente: conhecimento como expressão da ação humana. In: ROMANOWSKI, Joana Paulin; JUNQUEIRA, Sérgio Rogério Azevedo; MARTINS, Pura Lúcia Oliver. (Org.). Conhecimento local e conhecimento universal: pesquisa, didática e ação docente. ENCONTRO NACIONAL DE DIDÁTICA E PRÁTICAS DE ENSINO, 12., Curitiba, 2004. Curitiba: Champagnat, 2004.

NÓVOA, António. Formação de Professores e Trabalho Pedagógico. Lisboa: Educa, 2002.

NÓVOA, António. (Org.). Vidas de professores. Porto: Porto Editora, 1995.

THOMPSON, Edward Palmer. A miséria da teoria ou um planetário de erros. Rio de Janeiro: Zahar, 1981.

UNESCO. Pesquisa Nacional UNESCO. O perfil dos professores brasileiros: o que fazem, o que pensam, o que almejam. São Paulo: Moderna, 2004.

VIEIRA, Sofia Lerche. Ser professor: pistas de investigação. Brasília: Plano, 2002.

Submetido à publicação em 4 de março de 2013. Aprovado em 25 de junho de 2013. 